\title{
Leucoscypha ovilla n. comb., a species new to Europe, found in northern Finland
}

\author{
HARRI HARMAJA
}

\begin{abstract}
HARMAJA, H. 1977: Leucoscypha ovilla n. comb., a species new to Europe, found in northern Finland. - Karstenia 17: 73-76.

The author has found Peziza ovilla Peck (Pezizales), a species described from North America, in Kuusamo, northern Finland. This find is the first reported from Europe. The species is considered to belong to the genus Leucoscypha Boud. in its recently amended delimitation, and the following new combination is made: Leucoscypha ovilla (Peck) Harmaja. A description of $L$. ovilla is given, and the species is compared with the closely related $L$. rhodoleuca (Bres.) Svrček, type material of which has been examined. Both species possess exceptionally thick-walled excipular hairs, and their paraphysis cells contain four or two nuclei.

The nuclei of the cells of the apothecium of various species of Leucoscypha sensu lato, including the type species of the genus, are carminophilic. This feature, also observed previously in the genus, appears truly diagnostic of Leucoscypha and also supports the recently broadened delimitation of the genus.
\end{abstract}

Harri Harmaja, Botanical Museum, University of Helsinki, SF-00170 Helsinki 17, Finland

\section{Leucoscypha ovilla}

Leucoscypha ovilla (Peck) Harmaja, n. comb. Peziza ovilla Peck, Rep. New York St. Mus. 28: 66. 1876. - Neottiella ovilla (Peck) Sacc., Sylloge Fungorum ... 8: 194. 1889. - Patella ovilla (Peck) Seav., The North American cup-fungi (operculates): 163. 1928. - Type: see below.

Apothecia reaching a diameter of ca. $10 \mathrm{~mm}$, soon becoming broader than high and becoming shallower in age, sessile, cupulate; hymenium pink; margin even and smooth (i.e., without dentation or hairs); sterile surface, or exterior, also pink when fresh being then \pm concolorous with hymenium, covered with very fine tomentum, which is almost invisible to the bare eye and hyaline in fresh apothecia, but whitish in dry ones, where it is responsible for the faded very pale pink colour of their exteriors.

Excipulum indistinctly two-layered. Ental layer composed of textura intricata of thick-walled hyphae (apparently mixed with thin-walled ones) difficult to revive and 5-15 $\mu \mathrm{m}$ in diameter, cyanophilic septal collars of variable breadth (up to 1.0 $\mu \mathrm{m})$ present but very infrequent; ectal layer fairly similar to the ental part, probably best described as being composed of $t$. epidermoidea, in places tending towards $t$. porrecta, the hyphae having cells shorter than those in the ental part but equally thick-walled, cyanophilic intercellular matter lacking; in places the outermost cells give rise to undulate flexuous obtuse septate hairs, ca. 40-250 $\mu \mathrm{m}$ long and ca. $12-17 \mu \mathrm{m}$ in diameter, which have narrow lumina and thin hyphal walls proper but a very thick (4-7 $\mu \mathrm{m}$ in cotton blue, even thicker in Melzer's reagent and $\mathrm{KOH}$ ) smooth hyaline cyanophobic sheath, the hair cells being multinucleate; nuclei \pm carminophilic everywhere.

Paraphyses filiform, straight, septate, somewhat branched below, hardly enlarged apically, 4.5-7.5 $\mu \mathrm{m}$ in diameter apically, containing small red granules, which do not change colour in Melzer's reagent in dried apothecia; cells, including terminal one, multinucleate with mostly four or two \pm strongly carminophilic nuclei (only rarely apparently uninucleate).

Asci $230-270 \times 13-17 \mu \mathrm{m}$, operculate, maturing at different times within the same apothecium, cylindrical, eight-spored, apex slightly tapering and curved; wall with double structure discernible at least towards the apex, inamyloid, cyanophobic, carminophobic; ascostome very slightly eccentric.

Spores (in Melzer's reagent unless otherwise indicated) $32-38 \times 11.0-13.5 \mu \mathrm{m}$, fusiform $/$ navi- 
cular, inequilateral; primary wall ca. $0.5 \mu \mathrm{m}$ thick in mature spores; secondary wall (perisporium) persistent but thinning greatly towards maturity (the spores belonging to the Peziza type of Harmaja 1974c), continuous, strongly cyanophilic, smooth, evenly appressed to the primary wall; contents hyaline to golden yellow (especially in Melzer's reagent), cyanophobic at maturity, with two large and some smaller oil drops in most spores and several small drops in the remainder (but in $5 \% \mathrm{KOH}$ usually one large ellipsoid drop in middle of spore), and with one asymmetrically located gaseous de Bary bubble in a minority of the mature spores; uninucleate with one central strongly to weakly carminophilic nucleus.

Ecology. The Finnish specimen was found on a brook-side in mixed coniferous and deciduous grassherb forest with very calcareous soil, the site apparently being flooded every spring. The brook ravine has an unusually rich flora of different plant groups and fungi, including many calcicolous and calciphilous species, both northern and southern ones; species lists representative of this flora are given in earlier papers (Harmaja 1974b: 116, 1976: 27-28). Both the specimens examined were collected from woody substrates: the North American one 'on bark of Betula lutea and very decayed wood of ?' (according to the label note), the Finnish one exclusively on dead mossy twigs of spruce (Picea abies; my determination of the substrate was confirmed by Dr. Maire Pyykkö, who kindly examined the wood anatomy) which were still covered with bark and were lying on the ground near the water's edge. The Finnish specimen fruited in late August, while the North American one was collected in early October.

Distribution in Europe. The Finnish site lies in the northern boreal zone (Ahti et al. 1968), $225 \mathrm{~m}$ above sea level, in the northeastern part of the country.

\section{Specimens examined}

Finland. Kuusamo: Oulanka National Park, the ravine of the brook Tulilammenpuro, seven apothecia, 26.VIII.1970 H. Harmaja (H). - U.S.A. New York: Slaterville, LloydCornell preserve, 4.X.1947 C.T. Rogerson \& R.P. Korf, det. as Peziza ovilla Peck by R.P. Korf 797 (CUP 37139).

\section{Discussion}

The above description is based solely on the Finnish specimen. In the paragraph on ecology, the notes on the label of the North American specimen are also included.

It is not without some hesitation that I assign the
Finnish specimen - and the conspecific North American one kindly lent for comparison by Prof. R.P. Korf - to Peziza ovilla Peck. When I asked for type material of this species from the Herbarium of the New York State Museum (NYS) in Albany, U.S.A., Dr. John H. Haines, the Senior Scientist, kindly informed me that, although such material may exist, it is not available at present. Thus the identification of the present material is based on the determination by Prof. Korf of the specimen CUP 37139 collected from the state of New York, i.e. the same state from which the type of $P$. ovilla originates. However, the identification of the present material cannot be considered completely certain as there appear to be slight discrepancies between it and Peck's protologue: (1) the hymenial colour of Peck's fungus was described as paler, being only faintly tinged with pink, (2) Peck did not mention the exceptionally thick walls of the excipular hairs, and (3) Peck's protologue gave the habitat/substrate as 'ground in woods'. Whether this is due to actual differences between the original $P$. ovilla and the present specimens or only to errors of observation, etc., can only be decided when the type material of Peck's species can be examined.

L. ovilla is a rare species also in North America and, as far as I know, the Finnish find is the first in Europe. Seaver (1942 and previous edition) reported it from Europe, but this was because he erroneously listed the European Humaria rhodoleuca Bres. (see below) as its synonym.

L. rhodoleuca (Bres.) Svrček (Humaria rhodoleuca Bres. 1898) appears to be very similar to, if not identical with, L. ovilla. However, I have compared type material of $H$. rhodoleuca, preserved in $\mathrm{S}$, with the present specimens, and found that they are two different, though closely related, species. L. rhodoleuca differs from $L$. ovilla (as interpreted in the present paper) mainly in the following respects: (1) the spores are distinctly longer, (37-)42-55 $\mu \mathrm{m}$ (in Melzer's reagent and cotton blue), (2) the spores are very slightly narrower, $11.0-12.5 \mu \mathrm{m}$, and thus clearly narrower in proportion to their length, being narrowly fusiform/navicular, (3) the spore shape is slightly more inequilateral, (4) the spore contents are different, only consisting of two large round oil drops (sometimes two small drops or one large drop in the middle), (5) the cyanophilic secondary wall (perisporium) does not become thinner towards maturity, and (6) the substrate from which the apothecia emerge is bare soil. L. rhodoleuca is also an infrequent species. The few notes published on it include that of Svrček (1974). It is not known from Finland. 
Neottiopezis macrospora Clements 1903 is apparently closely related to $L$. ovilla and $L$. rhodoleuca. However, unfortunately its characters cannot be examined by modern methods, since neither Eckblad (1968) nor I myself (even using a dissecting microscope) could detect any fungal material referable to Pezizales in the holotype envelope preserved in BPI. In any case, the protologue of $N$. macrospora does not mention conspicuously thickened hair walls, the spores were given as asperulate, and the description of the excipulum indicates that it was different from those of $L$. ovilla and L. rhodoleuca.

\section{Notes on generic taxonomy}

The present material of $L$. ovilla and the authentic specimen of $L$. rhodoleuca studied display three very noteworthy features, which might be taken to justify the establishment of a new genus. The first of these characters is the unusual thickness of the sheath of the external hairs of the apothecium. Wells and Kempton (1967) write of these hairs in $L$. ovilla, but I do not know any other mention of such hairs in the literature. The proper hyphal walls of the hairs are not thickened and are distinguished from the sheath by being refractive.

The second distinctive character is the strongly carminophilic nuclei of the cells of the apothecium. In the order Pezizales, this feature has been known as diagnostic of Tarzetta (Cooke) Lamb. and Jafnea Korf (see e.g. Korf 1972). In addition, somewhat carminophilic spore nuclei have been observed in Helvella St-Am. (Harmaja 1974a: 111), and 'carminophilic nuclei have recently been noted' in Leucoscypha (Dr. H. Dissing's observation, quoted from Korf 1972; no particular species mentioned).

The third notable feature is the number of nuclei in the paraphysis cells, which is practically always more than one, generally four or two. The number varies among the representatives of the Pezizales examined so far (Berthet 1964, Harmaja 1974d), and its taxonomic significance cannot yet be properly evaluated.

A specimen belonging to Leucoscypha leucotricha (Alb. \& Schwein.) Boud., the lectotype species of the genus Leucoscypha Boud., was examined carefully to determine whether $P$. ovilla (and $H$. rhodoleuca) is congeneric with this species (as it appeared to me and had already been concluded by Svrček 1974 in respect of $H$. rhodoleuca). The specimen studied is the holotype of Peziza nivea Romell (S Herb. L. Romell no. 16443), determined as $L$. leucotricha by Le Gal (1957). I observed that the nuclei of the spores, excipular cells, hair cells, and paraphysis cells are distinctly carminophilic, and the paraphysis cells are tetranucleate or binucleate. The hair walls are somewhat thickened, especially in the flexuous basal parts of the hairs, up to about 3.5 $\mu \mathrm{m}$, and the wall structure is exactly the same as in $L$. ovilla and $L$. rhodoleuca, i.e. a thin refractive hyphal wall proper with a (somewhat) thickened sheath of mat hyaline cyanophobic matter. In other words, the difference between the hairs of $L$. leucotricha on the one hand and L. ovilla and $L$. rhodoleuca on the other is quantitative only and not of generic rank. These three species also proved very similar in other respects, e.g. in the above-mentioned cytological characters, the spore wall structure, and excipular anatomy, and I consider them definitely congeneric.

The fact that the type species of Leucoscypha has now been proved to possess carminophilic nuclei is very important for the delimitation of this genus. I have also detected carminophilic nuclei in an authentic specimen (preserved in PAD) of L. (Neottiella) patavina (Cooke \& Sacc.) Svrček, in $L$. (Neottiella) rutilans (Fr.) Dennis \& Rifai, and in the holotype of Peziza albocincta Berk. \& Curt. (preserved in $\mathrm{K}$ ), the last-named species being the lectotype of the genus Neottiella (Cooke) Sacc. This strongly supports the broadened generic concept of Leucoscypha that includes Neottiella. Some of the grounds for this ampler delimitation were mentioned earlier, especially by Le Gal (1957), but it was in the studies of Rifai (1968) and Eckblad (1968) that the genera were first merged in practice, and the Neottiella species were actually transferred to Leucoscypha.

The thickness of the sheath of excipular hairs thus varies within the genus Leucoscypha, L. ovilla and $L$. rhodoleuca being at present the only species known to have a very thick sheath (the latter being thin in e.g. $L$. albocincta, $L$. leucotricha, $L$. patavina and $L$. rutilans). I have observed that the cells, including the terminal ones, are tetranucleate or binucleate (a few may contain another number of nuclei, mostly three or one) in the paraphyses of $L$. leucotricha, $L$. ovilla, $L$. patavina, and $L$. rhodoleuca, but mostly binucleate in those of $L$. rutilans. This variability, too, is best considered infrageneric.

Acknowledgements. Type or other material and valuable information were received from the following herbaria: BPI, CUP, K, NYS, PAD, and S. I am most grateful to their directors and curators for their help and co-operation. I appreciate the opportunity, given me by the University of Oulu, to use the Oulanka Biological Station in Kuusamo, North Finland, as a base for my field work. 


\section{References}

Ahti, T., Hämet-Ahti, L. \& Jalas, J. 1968: Vegetation zones and their sections in northwestern Europe. Ann. Bot. Fennici 5: 169-211.

Berthet, P. 1964: Essai biotaxinomique sur les Discomycètes. - $157 \mathrm{pp}$. Lyon.

Eckblad, F.-E. 1968: The genera of the operculate Discomycetes. A re-evaluation of their taxonomy, phylogeny and nomenclature. - Nytt Mag. Bot. 15: 1-191.

Harmaja, H. 1974a: Two new families of the Pezizales: Karstenellaceae and Pseudorhizinaceae. - Karstenia 14: 109-112.

- »-1974b: Tarzetta pusilla n. sp. and T. spurcata (Pers.) n. comb. from Finland. - Karstenia 14: 116-120.

- $\gg-1974 c$ : Observations on the presence of a cyanophilic perispore in the spores of the Pezizales. - Karstenia 14: $123-125$.

- »-1974d: The generic limit between Otidea and Tarzetta
(Pustularia auct.). - Karstenia 14: 138-142.

Korf, R.P. 1972: Synoptic key to the genera of the Pezizales. - Mycologia 64: 937-994.

Le Gal, M. 1957: Le genre Leucoscypha Boud. - Bull. Jard. Bot. Etat Bruxelles 27: 719-728.

Rifai, M.A. 1968: The Australasian Pezizales in the herbarium of the Royal Botanic Gardens Kew. - Verh. Kon. Nederlandse Akad. Wetensch., Afd. Natuurk., Tweede Sect., 57(3): 1-295.

Seaver, F.J. 1942 (reprint 1961): The North American cupfungi (operculates). - Suppl. ed. 377 pp., 74 pls. New York.

Svrček, M. 1974: New or less known Discomycetes 1. Nové nebo méně známé discomycety 1. - Ceská Mykol. 28: $129-137$

Wells, V.L. \& Kempton, P.E. 1967: Studies on the fleshy fungi of Alaska 1. - Lloydia 30: 258-268.

Accepted for publication

on June 9, 1977 